\title{
Knowledge about infection control measures among nurses at Hawler Teaching Hospital in Erbil city
}

Accepted: 21/6/2015

\begin{tabular}{|c|c|}
\hline \multicolumn{2}{|c|}{ Ronak N.H * } \\
\hline \multicolumn{2}{|c|}{ Abstract } \\
\hline \multicolumn{2}{|c|}{$\begin{array}{l}\text { Background and objective: A lack of knowledge regarding infection control measures } \\
\text { among health care workers decreases compliance with these practices. This study aimed } \\
\text { to assess the knowledge of infection control measures among nurses in Hawler Teaching } \\
\text { Hospital. } \\
\text { Methods: A cross-sectional study was conducted from December } 15^{\text {th }}, 2013 \text { to February } \\
10^{\text {th }}, 2014 \text { on a non-probability purposive sample of } 50 \text { nurses. Data were collected by } \\
\text { self report by nurses that work in some critical care wards (dialysis unit, surgical and } \\
\text { neurosurgery) in Hawler Teaching Hospital. The questionnaire included two parts. Part one } \\
\text { was related to the nurses' sociodemographic characteristics, which contained six items of } \\
\text { age, gender, educational level, years of experience, attending training and place of work. } \\
\text { Part two was related to nurses' knowledge on standard precautions measures. } \\
\text { Results: There was positive correlation between nurses' knowledge on infection control } \\
\text { measures and their educational level, years of experience and attending training. About } \\
54 \% \text { of nurses had good knowledge on infection control measures and } 46 \% \text { of them had } \\
\text { fair knowledge. Mean knowledge about infection control measures of nurses was } 68 \% \text {. } \\
\text { Conclusion: The infection control knowledge among the nurses was fairly good in this } \\
\text { study. Older age was an important determinant of lower level of knowledge. } \\
\text { Keywords: Nurses' knowledge; Infection control; Universal precautions. }\end{array}$} \\
\hline roduction & \\
\hline $\begin{array}{l}\text { Universal precautions (UPs) as defined } \\
\text { by the Center for Disease Control and } \\
\text { Prevention are a set of precautions } \\
\text { designed to prevent the transmission of } \\
\text { blood borne pathogens when providing } \\
\text { health care. Under UP principles, the } \\
\text { exposure incidents can be significantly } \\
\text { decreased by using personal protective } \\
\text { barriers like gloves, face mask, protective } \\
\text { eyewear, overhead cap and gowns in } \\
\text { addition to hand washing after gloves } \\
\text { disposal, unrecapping needles, hygienic } \\
\text { disposal of medical wastes, and } \\
\text { sterilization of surgical instruments. } \\
\text { Health care associated infections (HCAls) } \\
\text { causes considerable morbidity and } \\
\text { mortality, and additional costs. The } \\
\text { prevalence of HCAl varies widely across } \\
\text { the globe. Worldwide, it is estimated } \\
\text { that almost } 10 \% \text { of the hospitalized patients }\end{array}$ & $\begin{array}{l}\text { of HCAl in developing countries can } \\
\text { become as high as } 30-50 \% \text {. The total } \\
\text { number of patients acquiring HCAI in the } \\
\text { European Union every year is estimated at } \\
3 \text { million, with } 50,000 \text { deaths per year as } \\
\text { a consequence. } 3,4 \text { HCAls are a serious } \\
\text { patient safety issue. In the United States, it } \\
\text { is estimated that nearly } 90,000 \text { patients } \\
\text { who acquire HCAls die each year. This } \\
\text { ranks HCAls as the fifth leading cause of } \\
\text { death in acute care hospitals. The most } \\
\text { important mechanism of spread of these } \\
\text { HCAI is via the contaminated hands of the } \\
\text { healthcare givers that is doctors, nurses, } \\
\text { other staff or relatives/friends of the } \\
\text { patients. Contaminated environmental } \\
\text { surfaces are another important reservoir } \\
\text { for spread of these infections., }{ }^{5,6} \text { Nurses are } \\
\text { at risk of various occupational hazards in } \\
\text { the hospital, including exposure to blood }\end{array}$ \\
\hline
\end{tabular}

* Department of Nursing, College of Nursing, Hawler Medical University, Erbil, Iraq. 
borne infections such as HIV and hepatitis $B$ and $C$ virus (HBV and HCV) infection from sharps injuries and contact with body fluids. Developing countries, which account for the highest prevalence of HIV-infected patients in the world, also record the highest rate of needle-stick injuries. In addition, more than $90 \%$ of the occupational infections occur in developing countries. ${ }^{7}$ Infection control is a priority for all nurses and healthcare staff because the nurses having the most contacts with patients, understanding their knowledge, attitudes and practice patterns. Nurses, regardless of specialty, engage in the most direct contact with clients in healthcare settings. Additionally, existing literature has documented specific examples where nurses are implicated in the transmission of nosocomial infections. There is also some evidence which suggests that the spread of nosocomial infections could be related to a breakdown in knowledge, attitudes and practices among healthcare workers. ${ }^{6,8}$ This study aimed to assess the knowledge about infection control measures among nurses in Hawler Teaching Hospital in Erbil city.

\section{Methods}

This cross-sectional study was conducted to assess nurse's knowledge about the infection control measures. This study was conducted in those critical areas which are more exposed to risk of transmission of pathogens by contact with blood, body fluids, skin, and mucous membranes at Hawler Teaching Hospital in Erbil city as hemodialysis, surgical and neurosurgery wards from December $15^{\text {th }}, 2013$ to February $10^{\text {th }}, 2014$. A non probability purposive samples of 50 nurses was involved in the study. Data were collected by self report from nurses working in selected places of work through a specially designed questionnaire that was derived from other published studies. ${ }^{9,10}$ Questionnaires were distributed to nurses with the assistance of the manger and were completed during their morning and evening duty time. Before distribution of the questionnaire, the purpose of the study was explained to each respondent of nurses and informed consent for participation was obtained from each nurse. Approvals for carrying out this research was obtained from the Ethical Committee of the College of Nursing. The questionnaire comprised two categories of questions in English and Kurdish languages. The first one was related to sociodemographic characteristics which contained six items of age, gender, level of education, years of experience, attending training sessions and place of work. Years of experience of nurses were classified as $(\geq 8,9-16$, and 17-24) years. No one of them had less than 3 years of experience. The second part of the questionnaire was designed to reveal participants' knowledge about infection control measures which consisted of 30 multiple choice items with one score given for each correct item and zero for false items. The total items score was 30 . The nurses' knowledge scores were classified into three equal percentile levels of good (66.67-100), Fair or medium (33.34- 66.66), and poor (1-33.33)] after dividing the score on 30 and multiply to 100 $($ score $/ 30 \times 100) .{ }^{11,12}$ Data were analyzed through the application of descriptive statistical data analysis approach such as frequency, percentage, mean and standard deviation. Inferential data analysis approach such as Chi-square and Fisher's exact test were used to make association between different variables. When $P$ value $<0.05$ was considered significant, $\leq 0.01$ was high significant, $\leq 0.001$ was very high significant. The data were analyzed through the use of the statistical package for the social sciences (version 18).

\section{Results}

More than half $(58 \%)$ of nurses were in the age group 25-34 years old and possessed the higher mean knowledge score (22.14). About $56 \%$ of nurses were females and institute graduates, $26 \%$ of them were 
college graduates who possessed the higher mean knowledge score (24.23). About $44 \%$ of nurses had less than 8 years of experience who had the higher mean on of knowledge (22.41) than those that had longer experience. $82 \%$ of nurses were not trained on infection control measures, only18\% were trained who possessed the higher mean knowledge score (24.33) than non trainers. Regarding their working location, nurses who worked in dialysis unit obtained higher mean knowledge score (21.72) than those of neurosurgical ward (Table 1).

Table 1: Socio-demographic characteristics of 50 nurses.

\begin{tabular}{|c|c|c|c|c|c|}
\hline No. & $\begin{array}{l}\text { Socio- demographic characteristics } \\
\text { of nurses }\end{array}$ & No. & $(\%)$ & $\begin{array}{c}\text { Mean score } \\
\text { of nurse's } \\
\text { knowledge }\end{array}$ & S.D \\
\hline \multicolumn{6}{|l|}{ Age } \\
\hline $\begin{array}{l}35-44 \\
45-54 \\
\text { Total }\end{array}$ & & $\begin{array}{c}15 \\
6 \\
50\end{array}$ & $\begin{array}{c}(30) \\
(12) \\
(100)\end{array}$ & $\begin{array}{c}18.8 \\
16 \\
20.4\end{array}$ & $\begin{array}{l}2.042 \\
1.414 \\
3.435\end{array}$ \\
\hline \multicolumn{6}{|c|}{ Gender } \\
\hline Males & & 22 & $(44)$ & 20.86 & 3.454 \\
\hline Fema & & 28 & $(56)$ & 20.04 & 3.437 \\
\hline Total & & 50 & $(100)$ & 20.4 & 3.435 \\
\hline \multicolumn{6}{|c|}{ Educational levels } \\
\hline Colles & graduate & 13 & $(26)$ & 24.23 & 2.743 \\
\hline Institc & graduate & 28 & $(56)$ & 19.82 & 2.294 \\
\hline Nursil & schools & 9 & $(18)$ & 16.67 & 1.581 \\
\hline Total & & 50 & $(100)$ & 20.4 & 3.435 \\
\hline \multicolumn{6}{|c|}{ Years of experience } \\
\hline$\geq 8$ & & 22 & $(44)$ & 22.41 & 3.459 \\
\hline $9-16$ & & 19 & (38) & 19.74 & 2.257 \\
\hline $17-24$ & & 9 & (18) & 16.89 & 1.833 \\
\hline Total & & 50 & $(100)$ & 20.4 & 3.435 \\
\hline \multicolumn{6}{|c|}{ Attending infection control training } \\
\hline Yes & & 9 & $(18)$ & 24.33 & 2.646 \\
\hline No & & 41 & (82) & 19.54 & 2.967 \\
\hline Total & & 50 & $(100)$ & 20.4 & 3.435 \\
\hline \multicolumn{6}{|c|}{ Places of work } \\
\hline Dialys & unit & 18 & (36) & 21.72 & 3.997 \\
\hline Surgic & ward & 20 & $(40)$ & 19.75 & 2.863 \\
\hline Neurc & urgical ward & 12 & $(24)$ & 19.5 & 3.03 \\
\hline Total & & 50 & $(100)$ & 20.4 & 3.435 \\
\hline
\end{tabular}


Table 2 shows that the overall mean score of knowledge about infection control measure of nurses was $68 \%$.

Table 2: Frequency and percentage of correct response for each item about nurse's knowledge on infection control measures.

\begin{tabular}{|c|c|c|c|}
\hline No. & Nurses correct answers of multiple choice & $\begin{array}{c}\text { No. of } \\
\text { correct } \\
\text { answers } \\
\text { No. } 50\end{array}$ & $\begin{array}{c}\% \text { of } \\
\text { correct } \\
\text { answers }\end{array}$ \\
\hline 1 & $\begin{array}{l}\text { The most likely source of HIV and hepatitis B virus is blood } \\
\text { and bloody body fluids }\end{array}$ & 38 & $(76)$ \\
\hline 2 & $\begin{array}{l}\text { Hospital employees who may be exposed to blood and bloody } \\
\text { fluids must receive training every year. }\end{array}$ & 32 & $(64)$ \\
\hline 3 & During recapping a needle stick injury most likely to occur. & 35 & $(70)$ \\
\hline 4 & Recapping needles after use is violates standard precautions. & 27 & $(54)$ \\
\hline 5 & $\begin{array}{l}\text { Nurses were had the highest incidence of occupationally } \\
\text { acquired HIV. }\end{array}$ & 29 & $(58)$ \\
\hline 6 & $\begin{array}{l}\text { "Standard precautions" are designed to be used when risk of } \\
\text { transmission of pathogens by contact with blood, body fluids, } \\
\text { skin, and mucous membranes must be reduced. }\end{array}$ & 35 & $(70)$ \\
\hline 7 & $\begin{array}{l}\text { More years of experience with exposure to blood on the job } \\
\text { results in risk of hepatitis B healthcare workers. }\end{array}$ & 32 & $(64)$ \\
\hline 8 & $\begin{array}{l}\text { Standard precautions taken by healthcare workers are to be } \\
\text { applied uniformly to all hospitalized patients. }\end{array}$ & 35 & $(70)$ \\
\hline 9 & Hepatitis $B$ is a vaccine that currently available for nurses. & 37 & $(74)$ \\
\hline 10 & $\begin{array}{l}\text { The exposures of the hospital employee to blood borne } \\
\text { pathogens must be reported and documented according to } \\
\text { the employing institution's exposure control plan. }\end{array}$ & 29 & (58) \\
\hline 11 & $\begin{array}{l}\text { The sharps (needles, broken glass, etc.) should be disposed } \\
\text { in sharp container. }\end{array}$ & 35 & (70) \\
\hline 12 & $\begin{array}{l}\text { Common symptoms of TB. are coughing up blood, night } \\
\text { sweats and cough lasting more than } 2-3 \text { weeks }\end{array}$ & 32 & (64) \\
\hline 13 & $\begin{array}{l}\text { Gloves must be worn as a single-use item for contact with } \\
\text { sterile sites and non-intact skin or mucous membranes }\end{array}$ & 35 & (70) \\
\hline 14 & $\begin{array}{l}\text { The major hazard which face healthcare workers on the job is } \\
\text { hepatitis } B\end{array}$ & 36 & (72) \\
\hline 15 & $\begin{array}{l}\text { Hand washing should be performed before and after patient } \\
\text { contact, after removing gloves, any time contact is made with } \\
\text { environmental surfaces. }\end{array}$ & 32 & (64) \\
\hline \multicolumn{4}{|c|}{ Cont: } \\
\hline
\end{tabular}


16 The guideline for isolation published by the Centers for Disease Control and prevention (CDC) should be used in all health care setting

17 The most important measure that should be taken to reduce the risk of disease transmission is hand washing

39

18 The risk of hepatitis $C$ transmission to healthcare workers, after a needle stick injury greater than HIV.

19 Transmission of HIV is most common when contact involving penetration of the skin, such as needle stick injuries.

20 Transmission-based precautions used in healthcare are droplet, airborne, and contact precautions.

$21 \quad$ Hand washing is the single important mean of preventing disease transmission

22 Germs can be spread by contact, droplet and airborne forms working within 3 feet of the patient, 2- make sure the patient is wearing a surgical mask, 3- meningitis is an example of an illness spread by droplets.

26 With airborne precautions: 1- the patient must be in a negative pressure room, 2- the caregiver must put on a mask before going into the patient's room, 3- tuberculosis is an illness which is spread by airborne germs,4- keep the patient's room closed.

27 Prevent germs from spreading when someone is coughing are by 1 - mask the person who is coughing, 2- the coughers should cover their cough with tissue and then clean their hands, 3- wear a mask while within coughing range (usually 3 feet) of someone who is coughing.

28 A patient presents with a productive cough and open wounds should placed with droplet contact precautions

29 To enter a patient room when Droplet Precautions are in place I wear: mask with eye shield

30 When working with patients who require contact precautions: 1- perform hand hygiene and put on gloves and gown, 2- ensure that clothing and skin do not contact contaminated surfaces, 3- removes gown and gloves and performs hand hygiene after caring.

Total number of items $=30 \quad \mathrm{~N}=50 \quad$ Over all percentile mean $=68 \%$


Table 3 shows that there was statistically significant relationship between nurses knowledge on infection control measures and nurses' age, gender, educational level, years of experience, attending training $(P$ $=0.002,0.044,<0.001,0.004$ and 0.002 , respectively). Nurses who had good knowledge were $\leq 34$ years of age, males, college graduates, those had less than 8 years of experience and those attending training $(62.1 \%, \quad 59.1 \%, \quad 92.3 \%, \quad 63.6 \%$ and $88.9 \%$, respectively). Most of females and those not attending infection control training had fair knowledge on infection control measures $(71.4 \%$ and $68.3 \%$, respectively). Table 4 shows that more than half $(54 \%)$ of the nurses had good knowledge of infection control measures and $46 \%$ of them had fair knowledge.

Table 3: Association between sociodemographic characteristics of 50 nurses with their levels of knowledge on infection control measures.

\begin{tabular}{|c|c|c|c|c|c|c|}
\hline \multirow{3}{*}{\multicolumn{2}{|c|}{$\begin{array}{l}\text { Socio - demographic } \\
\text { characteristics of nurses }\end{array}$}} & \multicolumn{4}{|c|}{ Levels of nurses knowledge } & \multirow{3}{*}{$\begin{array}{c}P \text { value } \\
\text { Fisher exact* } \\
\text { or Chi-square Test }\end{array}$} \\
\hline & & \multirow{3}{*}{$\begin{array}{l}\text { Fair } \\
\text { No. }\end{array}$} & \multirow{3}{*}{$\%$} & \multicolumn{2}{|c|}{ Good } & \\
\hline & & & & No. & $\%$ & \\
\hline \multirow[t]{5}{*}{1} & Age of Nurses & & & & & \\
\hline & $25-34$ years & 11 & $(37.9)$ & 18 & $(62.1)$ & \\
\hline & $35-44$ years & 12 & $(80.0)$ & 3 & (20.0) & \\
\hline & 45- 54 years & 6 & $(100.0)$ & 0 & $(0.0)$ & \\
\hline & Total & 29 & $(58.0)$ & 21 & $(42.0)$ & 0.002 \\
\hline \multirow[t]{4}{*}{2} & Gender & & & & & \\
\hline & Males & 9 & $(40.9)$ & 13 & $(59.1)$ & $0.044^{*}$ \\
\hline & Females & 20 & $(71.4)$ & 8 & $(28.6)$ & \\
\hline & Total & 29 & $(58.0)$ & 21 & $(42.0 \mathrm{v}$ & \\
\hline \multirow[t]{5}{*}{3} & Educational levels & & & & & \\
\hline & College graduate & 1 & $(7.7)$ & 12 & $(92.3)$ & \\
\hline & Institute graduate & 19 & $(67.9)$ & 9 & $(32.1)$ & $<0.001$ \\
\hline & Nursing schools & 9 & $(100.0)$ & 0 & $(0.0)$ & \\
\hline & Total & 29 & $(58.0)$ & 21 & $(42.0 \mathrm{v}$ & \\
\hline \multirow[t]{5}{*}{4} & Years of experience & & & & & \\
\hline & 1-8 years & 8 & $(36.4)$ & 14 & $(63.6)$ & \\
\hline & $9-16$ years & 12 & (63.2) & 7 & $(36.8)$ & 0.004 \\
\hline & $17-24$ years & 9 & (100.0) & 0 & $(0.0)$ & \\
\hline & Total & 29 & $(58.0)$ & 21 & (42.0) & \\
\hline \multirow[t]{4}{*}{5} & Attending training on in & contro & & & & \\
\hline & Yes & 1 & $(11.1)$ & 8 & $(88.9)$ & \\
\hline & No & 28 & (68.3) & 13 & $(31.7)$ & $0.002^{x}$ \\
\hline & Total & 29 & $(58.0)$ & 21 & $(42.0)$ & \\
\hline \multirow[t]{5}{*}{6} & Places of work & & & & & \\
\hline & Dialysis unit & 8 & $(44.4)$ & 10 & $(55.6)$ & \\
\hline & Surgical ward & 13 & $(65.0)$ & 7 & $(35.0)$ & 0.345 \\
\hline & Neuro surgery & 8 & $(66.7)$ & 4 & (33.3) & \\
\hline & Total & 29 & $(58.0)$ & 21 & $(42.0)$ & \\
\hline
\end{tabular}

Table 4: Distribution of overall knowledge level scores among nurses.

\begin{tabular}{lcc}
\hline Levels of knowledge score & No. & $\%$ \\
\hline Fair (medium) & 23 & $(46.0)$ \\
Good & 27 & $(54.0)$ \\
Total & 50 & $(100.0)$ \\
\hline \hline
\end{tabular}




\section{Discussion}

In this study the result shows that more than half of nurses were in the age group between 25-34 years old, females and institute graduates. Less than half of them had 8 years or less of experience. Most of them were not trained on infection control measures. Knowledge of infection control measures by nurses may be influenced by their type of training. Nurses are faced with professional hazards in their day-to-day activities in the work place they need training to increase their compliance with standard precautions. These results agreed with the results of other studies from India and Egypt, ${ }^{13,14}$ with most of their samples being young, females, having lower years of experience and not trained on infection control measures. The finding of the current study shows that there were statistical significant relationships between nurse's knowledge on infection control measure and nurse's age, gender, educational level, and years of experience and attending training. Positive correlation has been found between nurse's educational level, years of experience and attending training and their knowledge on infection control measure. These findings are agreed with the results of two studies from India and Kuwait ${ }^{13,15}$ which stated that there were correlations between nurses' knowledge on infection control knowledge and demographic variables such as age, length of clinical experience and number of relevant training attended, while this result disagree with a study from Philippine ${ }^{16}$ which found that nurses regardless of their age, gender, length of clinical experience, and numbers of trainings attended did not differ in knowledge on sterile technique practices. Good level of knowledge on infection control measures was with younger nurses of 25-34 years, college graduates, lower year of experience ( $\geq 8$ years) and those attending training on infection control measures. Fair nurse's knowledge on infection control measures was with older nurse (45-54 years of age), females, nursing school graduate, longer years of experiences (17-24 years), and nurses not attending infection control training. Those results were along with the results of Indian and Kuwaitian studies. ${ }^{13,15}$ The younger nurses had more knowledge on infection control measures than the older. This may be related to the fact that in elders the efficacy of initial education decreases and they were under stress, or carelessness. This finding is in agreement with that of results of other studies from Kuwait, India and Italy. ${ }^{15,17,18}$ They reported that older age was an important determinant of lower level of knowledge. Younger nurses were more knowledgeable than older nurses. The college graduate nurses had more knowledge on infection control measures than institute and nursing school graduates. This result is compatible with finding of the studies done in India and Italy. 13,18 They found that nurses with higher educational level had higher perception and knowledge with regards to infection control. Nurses who had higher years of experience had lower knowledge of infection control measures while nurses with lower years of experience had higher knowledge. This result is supported by results of the studies in Kuwait, India, Italy. ${ }^{15,17,18}$ They stated that nursing staff having more than 10 years of experience showed a decline in their level of knowledge of infection control. According to attendance to infection control training course, most of trained nurses had good knowledge on infection control while low knowledge was with non trained nurses. This result agree with the result of a study from Egypt ${ }^{14}$, which showed that nurses whom received infection control training were more knowledgeable and had positive attitude toward most aspects of infection control. This finding disagrees with the study done on Nepalese health care workers who stated that although $27 \%$ of nurses received infection control training course they had good knowledge and positive attitudes toward most aspects of infection control. ${ }^{19}$ In this study, more than half of nurses had good knowledge on 
infection control measures while less than half had fair knowledge. This may be related to majority of nurses were institute graduates. This finding is similar to the finding of the studies conducted on Iranian, Indian and Kuwaitian nurses, ,13,15 which found that nurses had average knowledge on infection control. This disagrees with a study from New York $^{6}$ that found that the nurses demonstrated high levels of knowledge, adherence to recommended guidelines of infection control practices.

\section{Conclusions}

The study concluded that about half of nurses were had good knowledge on infection control measures. Overall mean of nurse's knowledge on infection control measures was $68 \%$. There were positive correlation has been found between nurses' educational level, years of experience and attending training course and their knowledge on infection control measures.

\section{Conflicts of interest}

The author reports no conflicts of interest.

\section{References}

1. Johnson OE, Asuzu MC, Adebiyi AO. Knowledge and Practice of Universal Precaution among Professionals in Public and Private Health Facilities in Uyo, Southern- Nigeriaa Comparative Study. Ibom Med J 2012; 5(1): 9-19.

2. Buowari OY. Universal Precautions: A Review. The Nigerian Health J 2012; 12(3):68-74.

3. Jain M, Dogra V, Mishra B, Thakur A, Loomba PS. Infection control practices among doctors and nurses in a tertiary care hospital. Ann Trop Med Public Health 2012; 5:29-33.

4. Qalawa SA, Mahran SM, Alnagshabandi E. Investigations of factors influencing nurses compliance with standard precautions in critical care areas. Asia Acad Res J 2014; 21(1):177-200.

5. Ghadamgahi F, Zighaimat F, Ebadi A, Houshmand A. Knowledge, attitude and self-efficacy of nursing staffs in hospital infections control. Ir $\mathrm{J}$ Mil Med 2011; 13(3):167-72.

6. Kamunge EW. Exploring Knowledge, Attitudes and Practices of Registered Nurses Regarding the Spread of Nosocomial Infections. PhD dissertations, Seton Hall University, School of Health and Medical Sciences; 2012.

7. Sreedharan J, Muttappillymyalil J, Venkatramana
M. Knowledge about standard precautions among university hospital nurses in the United Arab Emirates. East Mediterr Health J 2011; 17(4):331-4.

8. Mahmud NA, Abul Sahib SH. Assessment of nurses' practices toward infection control standardized precautions in Azady Teaching Hospital in the City of Kirkuk. Iraq Natl J Nursing Specialties $2011 ; 24(1): 52-8$.

9. Logan CA. Nursing students' knowledge, observation of Environmental risk factors, and compliance with recommended precautions for the Prevention of transmission of infectious Diseases by needlestick injury PhD dissertation. Louisiana State University, College of Agricultural and Mechanical.United States; 2002.

10. Infection Control Orientation Self-Study Guide .Rancho Los Amigos National Rehabilitation Center Infection Control Department; 2010. \{Cited 2014 Feb 24\} Available from:

file.lacounty.gov/dhs/cms1_218120.pdf

11. Suchitra JB, Devi LN. Impact of education on knowledge, attitudes and practices among various categories of health care workers on nosocomial infections. Indian J Med Microboil 2007; 25(3):181 $-7$.

12. Bogaert $\mathrm{PV}$, Meulemans $\mathrm{H}$, Clarke $\mathrm{S}$, Vermeyen K, Heyning KP. Hospital nurse practice environment, burnout, job outcomes and quality of care: test of a structural equation model. J Adv Nurs 2009; 65(10):2175-85.

13. Vij A, Swapna N, Williamson, Gupta S. Knowledge and practice of nursing staff towards infection control measures in a tertiary care hospital. J Acad Hosp Adm 2013; 13(2):1-6.

14. Ahmed S, Mamoud S, Hassan A, Abbas S, Shokry AE. Compliance with universal precautions among nurses and laboratory technicians in Mansoura International Specialized Hospital. Egyptian Journal of Hospital Medicine 2008; 30:151-64.

15. Alwutaib $\mathrm{AH}$, Abdulghafour $\mathrm{YA}$, Alfadhli AK, Makboul G, El-Shazly MK. Knowledge and attitude of the physicians and nurses regarding blood borne infections in primary health care, Kuwait. Greener J Med Sci 2012; 4:107-14.

16. Labrague LJ, Dolores L, Arteche DL, Yboa BC, Pacolor NF. Operating Room Nurses' Knowledge and Practice of Sterile Technique. J Nurs Care 2012 1:4

17. Foster TM, Lee MG, McGaw CD, Frankson MA. Knowledge and practice of occupational infection control among healthcare workers in Jamaica. West Indian Med J 2010; 59(2):147-52.

18. Sessa A. Giuseppe GD, Albano L, Angelillo IF. An Investigation of Nurses' Knowledge, Attitudes, and Practices Regarding Disinfection Procedures in Italy BMC Infect Dis 2011; 11:148.

19. Paudyal $P$, Simkhada $P$, Bruce J. Infection control knowledge, attitude, and practice among Nepalese health care workers. J Infect Control 2008; 36(8):595-7. 